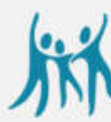

ACHNR

\section{Asian Community Health Nursing Research}

Asian Comm. Health Nurs. Res. 2020, 2(3), 39-43

\title{
The Effect of Stimulated Group Interaction on Pre- School Children's Social Development
}

\section{Tri Sakti Widyaningsih ${ }^{\mathrm{a}^{*}}$ and Tamrin ${ }^{\mathrm{b}}$}

Ners Diploma Program Lecture of Widya Husada University Semarang, Indonesia; imoet.sakti@gmail.com,ns.tamrin86@gmail.com

*Correspondence: imoet.sakti@gmail.com,

Type of the Paper (Article)

Received: October 28, 2020; Accepted: February 2, 2021; Published: March 14, 2021 https://doi.org/10.29253/achnr.2020.23956

\begin{abstract}
Background-Children's social abilities do not develop automatically. Children who are not able to socialize are very likely to be rejected by other colleagues, so that the learning process will be hampered and fail in the world of education. RA Islamic Tunas Bangsa 4 Semarang City, accepts 5 year old children who have just entered the school environment. In schools there are no special programs to improve social development. Purpose-Therefore the aim of this study is to determine the effect of stimulating group interaction on the social development of preschool children in RA Islamic Tunas Bangsa 4 Semarang City. Research Methods-The research method used was a quasi experiment, with One Group Pretest and Posttest Design. Sampling using total sampling, namely 36 respondents. The intervention given was stimulation of group interactions for 2 weeks. Observation data collection 1 week after treatment and analyzed using the Wilcoxon test. The results showed that the value of $\mathrm{Z}$ hitung -2.333 and $p$ value of 0.020 with a significant level of $5 \%$. Findings $-\mathrm{H} 0$ was rejected and Ha was accepted, meaning that there was an effect of stimulating group interaction on the social development of preschool children in RA Islamic Tunas Bangsa 4 Semarang City. Conclusion-Through stimulation of group interaction with the game of snakes and ladders, children can cooperate, adapt, interact positively, develop empathy for friends and respect for others.
\end{abstract}

Keywords: social development; stimulation; group interaction; snake and ladder game

\section{Introduction}

Humans are social beings who have the urge to relate or interact with other people, as well as in childhood, this is the earliest period in the life span that will determine development at later stages. Children aged 3-6 years, or the preschool period is a period called the golden age where children's socialization is still very sensitive and egocentric, by highlighting themselves, their families and their own (Wong, McElwain, \& Halberstadt, 2009).

According to Surna (2014), when children enter school / non-formal environments such as Playgroups (KB) to Kindergarten (TK), the space and opportunities for interaction are wider. In order to become a complete person, children at preschool age apart from having various skills must also have the ability to socialize. Children's socialization skills do not develop automatically but are influenced the environment treats them. Socialization has a strategic position for children to be able to build relationships in various environments, failure in socialization causes a person to be shy, less confident, 
aloof, stubborn. The socialization process is an activity that aims to make someone obey the rules and values that apply and to respect them (Soetjiningsih, 2016).

Children who lack social skills are very likely to be rejected by other colleagues. Children who are unable to cooperate, unable to adapt, unable to interact well, unable to control themselves, unable to empathize, unable to obey rules and unable to respect others will affect the development of other children. The development of social skills in children will lead to acceptance from peers, acceptance from teachers, and success in learning when the child is in education (Adriana, 2013).

According to Kusbiantoro (2015), that children interact with peers $10 \%$ of the time every day at the age of 2 years, $20 \%$ at the age of 4 years and more than $40 \%$ at the age between $7-11$ years. Relationships with peers strongly influence the development of a child, including in the field of adjusting to group demands, training children's independence in thinking and behaving, and most importantly the formation of a child's self-concept.

This influence is very much supported because at this time children tend to want to be accepted by the group and spend most of their time with their peers. Nearly $20 \%$ of children aged 4-6 years have a delay in adjustment, so they feel excluded, therefore stimulation is needed for children's social development (Handayani, 2012). Stimulation of child development is an activity to stimulate the basic abilities of children aged 0-6 years to develop optimally. Every child needs to get regular stimulation early and continuously at every opportunity. Stimulation of child development is carried out by mothers, fathers, child caregivers, other family members and community groups in the surrounding environment. This includes the stimulation provided by the teacher while at school. In addition, children are automatically "stimulated" by their playmates when playing games that are set by "game and interaction systems" which are also useful for their growth and development process (Andriana, 2013).

Striving for children to interact with the surrounding environment is one of the activities to support the stimulation of children's growth and development. Lack of stimulation can cause growth irregularities and even persistent disorders. The basic abilities of children that are stimulated by directed stimulation are gross movement skills, fine motor skills, speaking and language skills, and socialization and independence skills (Sulistyawati, 2014). Indicators of stimulation activities for early detection and development intervention for children under five in 2012 are expected to reach $90 \%$ of toddlers and preschool children by stimulation activities, while the coverage for early detection of growth and development of toddlers and preschool children at the provincial level of Central Java in 2012 was $36.66 \%$, decreasing compared to 2007 of $53.44 \%$. This shows that there is still a lack of stimulation of development, especially in social development (Susanto, 2011).

Based on statistical reports from the Ministry of Health of the Republic of Indonesia (2012) the coverage of under-five health services is $73.52 \%$ with the number of children under five with developmental disorders in Indonesia as much as $43.8 \%$, for Central Java province the detection of underfive growth and development is $82.86 \%$ with the number of children under five who experience growth and development disorders is $25.3 \%$. In Semarang, the data on the incidence of developmental delay is not yet known with certainty (it has not been studied extensively), but it is estimated that around 1-3\% of children under the age of 5 experience general developmental delays, especially social personal development (Kemendiknas. 2012).

Although it does not produce certain commodities, for example financial gain (money), parents must understand that the world of children is a world of play. Through games, children will get mental stimulation which is the embryo of the learning process to develop their intelligence (Susilaningrum, 2013). Children's games can be classified based on content and social characteristics. One of them is the cooperative play game, which is a game by playing together which is organized so that children learn to deal with problems that arise, learn to be responsible, recognize values and morals when dealing with other people (Susilaningrum, 2013). In line with this, the results of Kibtiyah's (2006) study entitled "The Effectiveness of Cooperative Games in improving Kindergarten children's social skills" concluded that cooperative play was effective in improving the social skills of kindergarten children, with significant results between the experimental group and the control group. $(t=10.191 ; p=0.000)$, the experimental group had higher social skills with $($ Mean $=111.857)$ than the control group $($ Mean $=53.893)$

According to research by Euis (2010) with the title "guidance program to develop children's social skills through traditional games", it shows that traditional games can play a positive role in the development of children's social skills. Through traditional games children can develop cooperation, be 
able to control themselves, have the ability to obey rules, and be able to respect others. In line with Euis's research by Ulya (2015) with the title "efforts to increase social interaction through traditional games of jamuran in children of group B TK Kuncup Sari Semarang" concluded that it was found that group B social interaction was still low before stimulating traditional games.

The results of preliminary studies that have been conducted at RA Islamic Tunas Bangsa Seamarang City, from the results of interviews with the principal that the social skills of children in the RA class are still low. It has been seen that 11 out of 36 children still like to be alone, indifferent to their surroundings, lack self-confidence, are shy, are silent when asked, do not want to hang out with friends and are still dependent on their parents / caregivers. 3 children are still frequently absent (not going to class), apart from the complaints that have been raised by 4 parents and 4 caregivers, namely about the child disliking school (school is not good), laziness to go to school for fear of being separated from their parents. In RA Islamic Tunas Bangsa 4 Semarang City, there is a regulation stating that parents should not wait during class hours, but from the observations it is still seen that parents / caregivers accompany children from the beginning of class to return, besides that, at RA Islamic Tunas Bangsa 4 Semarang City has never stimulated group interaction with the game of snakes and ladders, and there is no specific program regarding stimulating group interaction to improve social development. This condition illustrates that the social development of children still needs special attention, about children's preparation for entering elementary school age. This study aims to determine the effect of group interaction stimulation on the social development of preschool children in RA Islamic Tunas Bangsa 4 Semarang City.

\section{Methodology}

This type of research used in this research is quantitative. The population in this study were preschool children at RA Islamic Tunas Bangsa 4 Semarang City. The total population is 36 children. Sampling using total sampling technique. Nursalam (2013) say that total sampling is a sampling method by taking all members of the population, so that the sample used is 36 children.

The data collection method used is a quasi-experiment, with One Group Pretest and Posttest Design. The intervention given was stimulation of group interactions with snake and ladder games which were carried out for 2 weeks. Data collection by observation assessment 1 week after the treatment obtained the results of the highest score is 12 and the lowest is 1-3 with the category Social development has not developed if the score is 1-3, Social development begins to develop when the score is 4-6, Social development develops according to expectations if the score is 7-9, social development develops very well if the score is 10-12 then analyzed using the Wilcoxon test.

\section{Result}

Based on Table 1, the following conclusions can be drawn social development in preschool children at RA Islamic Tunas Bangsa 4 in Semarang City before the treatment / intervention was carried out, it was found that 15 children (41.7\%) had not developed well, 11 children (30.5\%) had social development, started to develop and 10 children (27.8\%) social development developed according to expectations.

Table 1. Social development of preschool children before stimulation at RA Islamic Tunas Bangsa 4.

\begin{tabular}{ccc}
\hline Social Development & Frequency (n) & Percentage (\%) \\
\hline BB & 15 & 41.7 \\
MB & 11 & 30.5 \\
BSH & 10 & 27.8 \\
BSB & 0 & 0 \\
Total & 36 & 100.0 \\
\hline
\end{tabular}


Table 2. Social Development of Preschool Children After Stimulation at RA Islamic Tunas Bangsa 4.

\begin{tabular}{ccc}
\hline Social Development & Frequency & Percentage (\%) \\
\hline BB & 4 & 11.1 \\
MB & 4 & 11.1 \\
BSH & 22 & 61.1 \\
BSB & 6 & 16.7 \\
Total & 36 & 100.0 \\
\hline
\end{tabular}

Table 2 explains the social development in preschool children at RA Islamic Tunas Bangsa 4 Semarang City after being given treatment / intervention, it was found that 4 children (11.1\%) had not developed social development, 4 children (11.1\%) began to develop children's social development, 22 children (61.1\%) developed social development according to expectations, and 6 children $(16.7 \%)$ developed very well.

Table 3. The Influence of Group Interaction Stimulation on Social Development of Preschool Children in RA Islamic Tunas Bangsa 4 Semarang City.

\begin{tabular}{cccc}
\hline Social Development & Frequency & $\begin{array}{c}\mathbf{Z} \\
\text { count }\end{array}$ & $\begin{array}{c}\mathbf{P} \\
\text { value }\end{array}$ \\
\hline Negative Rank & 0 & -2.333 & 0.020 \\
Positive Rank & 24 & & \\
Ties & 12 & & \\
Total & 36 & & \\
\hline
\end{tabular}

In Table 3 explains that 24 children experienced increased social interaction skills. There was influence of group interaction stimulation on the social development of preschool children at RA Islamic Tunas Bangsa 4 Semarang City through the game of snakes and ladders ( $p$ value $=0.020$ ), $\mathrm{Z}$ count $=-2.333$.

\section{Discussion}

The age of 5-6 years is the beginning of the child's social development with the outside world. This age factor greatly influences the stimulation that the child responds to, the more mature the organ system is, the more mature the physical, physical and social emotions are (Surna, 2014). From the observations it is clear that the average 4-year-old child is slightly more able to adapt and their development has begun to take shape. Unlike children who are 3 years old, they still feel embarrassed if they are invited to meet, this is because they are new to / entered the school environment where the space and opportunities for interaction are wider.

According to Soetjiningsih (2014), stated that high testosterone on a high scale will increase the risk of delayed social development in boys with high levels will experience a delay of 2 or 3 times greater than girls. In this study, it is known that the percentage of women and men is the same, namely 13 children (50\%). Even with the same percentage, it cannot be concluded whether the factor of testosterone plays a role in the high delay in child development or not because this study did not examine the blood testosterone content of each respondent.

Based on the above results, it can be seen that the factors that affect the delay in social development of children are caused by the lack of stimulation given by parents to children at home, this is due to the lack of knowledge of parents / caregivers about stimulation that must be given for growth and development, especially for their social development. , parenting styles with various types, for example, allowing children and tend to believe that social development develops naturally (Handayani, 2012).

The social development of children who continue / do not change even though they have been given this treatment is because children are often accompanied by their parents during the learning process so that children are not able to freely and have sufficient opportunities to carry out activities and get opportunities to make mistakes or learn from those mistakes. Whereas children whose social development is developing very well, this is because children are often given stimulation, especially 
stimulation for their social development, but also because of the high motivation from within the child so that there is a great desire to change (Suryono, 2011).

In line with Darsana's research (2012), the stimulation of group interactions identified through this study has the opportunity to develop children's social development. This can be seen from the number of respondents who have experienced a change in scores for each individual which is an indicator of a positive group interaction so that in the end it helps them to learn to develop their social development in a wider space and opportunity (school world).

\section{Conclusion and Suggestion}

There was influence of group interaction stimulation on the social development of preschool children at RA Islamic Tunas Bangsa 4 Semarang City through the game of snakes and ladders. This research is expected to add insight into nursing science. Where the results of this study can be used as information for nurses, especially in the field of child nursing, about appropriate stimulation to improve the social development of pre-school aged children.

\section{References}

Andriana, D. (2013). Growth and Development and Play Therapy in Children. Jakarta : Salemba Medika.

Darsana, W. (2012). The relationship between multiple intelligence stimulation and the personal social development of pre-school children. Be accessed on July.15, 2020

Handayani, A. (2012). The Relationship between Parents' Level of Knowledge About Verbal Stimulation and Language Development in Preschool Children at TK PGRI 116 Bangetayu Wetan. Essay. Semarang: Faculty of Nursing and Health Sciences, University of Muhammadiyah Semarang

Kemendiknas. (2012). Early Childhood Education Programs. from: www.Kemendiknas.com. Be accessed on July.12, 2020.

Kusbiantoro, D. (2015). Growth and development of preschool children at TK ABA 1 Lamongan. Surya, 7(1): 1-8

Kibtiyah, M. (2006). The Effectiveness of Cooperative Games in Improving Children's Social Skills. Accessed on April.12, 2016.

Euis, K. (2010). Guidance Program to Develop Children's Social Skills Through Traditional Games. Accessed on July.12, 2020

Nursalam. (2013). Nursing Research Methodology and Data Analysis Techniques. Jakarta : Salemba Medika.

Soetjiningsih. (2014). Child Development. Penerbit Buku Kedokteran. Jakarta: EGC.

Soetjiningsih. (2016). Child Development. Penerbit Buku Kedokteran. Ed 2. Jakarta: EGC.

Surna, IN. (2014). Psikologi Pendidikan 1. Jakarta : Erlangga

Suryono \& Hariyanto. (2011). Learning and Learning Basic Theory and Concepts. Bandung : Resda.

Susanto, A. (2011). Early Childhood Development, Introduction in Various Aspects. Jakarta : Prenada Media Group. Sulistyawati. (2014). Detection of child development. Jakarta: Salemba Medika.

Susilaningrum, Rekawati, dkk. (2013). Infant and Child Nursing Care. Jakarta : Salemba Medika.

Ulya \& Anita. (2015). Efforts to Increase Social Interaction through Traditional Jamuran Games for Group B Children at Tk Kuncup Sari Semarang School Year 2014/2015. Be accessed on July.12, 2020.

Wong, M. S., McElwain, N. L., \& Halberstadt, A. G. (2009). Parent, Family, and Child Characteristics: Associations with Mother- and Father-Reported Emotion Socialization Practices. Journal of Family Psychology 23, 452-463. http://dx.doi.org/10.1037/a0015552 